CASE REPORT

\title{
Chronic Burkholderia multivorans bronchial infection in a non-cystic fibrosis individual with mannose binding lectin deficiency
}

\author{
J L Whitehouse, A R Exley, J Foweraker, D Bilton
}

Thorax 2005;60:168-170. doi: 10.1136/thx.2003.016493

The case history is presented of a woman with multiple respiratory infections and mannose binding lectin (MBL) deficiency but no evidence of bronchiectasis who developed a chronic Burkholderia multivorans infection. Careful microbiological assessment is needed in patients with recurrent respiratory infection and the presence of $B$ multivorans should trigger further immunological investigation including assessment of MBL status.

$\mathrm{T}$ he pathogen Burkholderia multivorans (previously called Burkholderia cepacia, genomovar II) is well recognised in cystic fibrosis (CF) and chronic granulomatous disease (CGD). A previous report ${ }^{1}$ described a mother of two patients with CF who developed $B$ cepacia infection. We present a case of chronic $B$ multivorans infection in a woman with multiple respiratory infections and mannose binding lectin (MBL) deficiency but no evidence of bronchiectasis.

\section{CASE REPORT}

A 40 year old non-smoking woman presented to her GP in 1997 complaining of a productive cough and malaise. She was diagnosed with acute bronchitis and responded to amoxycillin ( $250 \mathrm{mg}$ three times daily for 7 days). In August 2000 she developed a flu-like illness associated with a productive cough, wheeze, and malaise and crackles on auscultation of her chest. Her symptoms continued for 1 month. There was a transient response to 5 days of treatment with amoxycillin ( $250 \mathrm{mg}$ three times daily) before she relapsed with a chronic cough productive of approximately $50 \mathrm{ml}$ mucopurulent sputum per day. The chest radiograph at that time was normal. In 2001 the patient required nine courses of oral antibiotics for respiratory infection. Sputum cultures in 2001 were persistently positive for Streptococcus pneumoniae with occasional co-isolates of Haemophilus influenzae and Moraxella catarrhalis. She was referred to the Lung Defence Clinic at this hospital in 2002.

The patient had had chronic sinusitis since the age of 12 years for which she was taking beclomethasone nasal spray ( $50 \mu \mathrm{g}$ per nostril twice daily) and intermittent courses of oral trimethoprim. She was diagnosed with mild asthma by her GP which was treated with Seretide 500 Accuhaler (salmeterol/fluticasone) one puff twice daily and salbutamol Diskhaler as required. In addition, she had developed epilepsy in her teens for which she took carbemazepine $400 \mathrm{mg}$ twice daily. There was a strong family history of asthma. She occasionally drank alcohol and denied any illicit substance use. On direct questioning, the patient complained of persistent heartburn and acid reflux which responded well to lansoprazole $30 \mathrm{mg}$ once daily.
On examination the patient had a small goitre but was clinically euthyroid. There was no finger clubbing. Her lungs were clear and the heart sounds were normal. Abdominal examination was unremarkable.

\section{Investigations}

Baseline blood tests including full blood count, renal and liver function, complement levels, and serum immunoglobulins were normal. Aspergillus precipitins were negative, as was an autoantibody screen. Aspergillus RAST in 2001 was negative. The chest radiograph was normal. High resolution computed tomography (HRCT) of the chest showed bronchial wall thickening in both lower lobes only. In particular, there was no evidence of bronchiectasis. Skin prick testing against a wide range of common environmental allergens including Aspergillus fumigatus was negative, and spirometric parameters were within the normal range. From October 2002 to July 2003 Burkholderia multivorans was cultured from seven of 15 sputum samples. Persistent culture of this organism prompted further immunological investigations.

The patient exhibited a poor specific antibody response to Pneumovax II, achieving antibody titres of $>1 \mu \mathrm{g} / \mathrm{ml}$ in only five of 10 serotypes tested, ${ }^{23}$ and $>1.3 \mu \mathrm{g} / \mathrm{ml}$ in only four of the 10 serotypes. ${ }^{4}$ Significant antibody responses were seen to serotypes 14, 18C and 19F, the main serotypes implicated in invasive disease in children, but of the five main serotypes implicated in adult disease only serotype 14 responses achieved threshold levels. ${ }^{5}$ Specific antibody responses to Neisseria meningitidis group C and Haemophilus group B vaccines were normal, and there was a significant antibody response to influenza $\mathrm{A}(\mathrm{H} 1 \mathrm{Nl}$ and $\mathrm{H} 3 \mathrm{~N} 2)$ but not to influenza B. Lymphocyte surface marker analysis showed a deficit of naïve/unprimed CD4+ CD45RA+ T cells, a substantial excess of both CD4+ CD8 dull cells (equivalent to approximately $12 \%$ of $\mathrm{CD} 4+\mathrm{T}$ cells), and $\mathrm{CD} 28$ negative $\mathrm{T}$ cells within both CD4+ and CD8+ T cells, similar to changes found in adult onset antibody deficiency. The CD4:CD8 ratio was normal. The patient was shown to be a heterozygote for an MBL coding region mutation (for genotyping method see Mullighan $e t a l^{6}$ ). MBL protein levels were not measured. The patient also displayed the CD32 (Fc $\gamma$ RIIA) homozygous Arg 131/Arg 131 allotype.

CF genetics to $85 \%$ of all known mutations were negative. The CF mutation screen was carried out using the CF 29 Elucigene assay which screens for delta F508 and the other 28 most common mutations in the UK population. A normal "neutrophil respiratory burst" excluded CGD.

\section{Management}

Initial management at this centre consisted of an admission for 10 days treatment with intravenous cefuroxime to treat $S$ pneumoniae isolated from sputum. Despite an improvement in her malaise and reduction in both cough and sputum 
Table 1 Summary of defects in the immune defences

\begin{tabular}{ll}
\hline Immunodeficiency & Clinical features \\
\hline MBL deficiency heterozygote & Susceptibility to Burkholderia complex \\
Specific pneumococcal antibody & $\begin{array}{l}\text { Recurrent Streptococcus pneumoniae } \\
\text { infections }\end{array}$ \\
deficiency & $\begin{array}{l}\text { As seen in adult onset antibody } \\
\text { deficiency }\end{array}$ \\
Arg131/Arg131 homozygous & $\begin{array}{l}\text { Associated with poor outcome from } \\
\text { Streptococcus pneumoniae } \\
\text { allotype for CD32 }\end{array}$ \\
& bacteraemia \\
\hline
\end{tabular}

production, she relapsed within a week of discharge. At this stage a Gram negative bacillus isolated from the pretreatment sputum was identified by the reference laboratory as $B$ multivorans. $B$ multivorans was grown from further sputum samples taken in the following few weeks as the patient's symptoms deteriorated. She was readmitted to hospital for a 14 day course of intravenous tobramycin and ceftazidime. Her symptoms improved and sputum samples over the next month failed to grow $B$ multivorans. Subsequent samples associated with worsening symptoms have grown $B$ multivorans.

\section{DISCUSSION}

Burkholderia multivorans forms part of the Burkholderia complex, a group of Gram negative organisms which are commonly found in soil and water. The Burkholderia complex was initially described as a plant pathogen, causing sour skin in onions. ${ }^{7}$ It has become an important pathogen in certain patient groups, particularly those with $\mathrm{CF}^{8}{ }^{8} \mathrm{CGD},{ }^{9}$ and as an unusual cause of nosocomially acquired outbreaks of infection in non-CF patients-for example, from contaminated equipment in intensive care. ${ }^{10} \mathrm{~B}$ cenocepacia (formally known as $B$ cepacia genomovar III) and $B$ multivorans (formally known as $B$ cepacia genomovar II) are most commonly isolated from patients with CF or CGD. B cenocepacia is highly transmissible, unlike $B$ multivorans which, although reported to be transmissible between CF patients, is not usually associated with nosocomial outbreaks. ${ }^{11}$

In an attempt to establish an underlying cause for $B$ multivorans infection, this patient was tested for CF and CGD. Although genetic screening rules out $85 \%$ of CF mutations, full sequencing of the CFTR gene may reveal a rare mutation. We feel the absence of bronchiectasis in this setting, given the recurrent infections documented, made CF an unlikely cause of the clinical problem. The patient also had no family history suggestive of CF and had three healthy children.
Normal neutrophil activity excluded CGD. The patient had not knowingly been in contact with other patients infected with Burkholderia complex and had not been admitted to hospital (a known risk factor for Burkholderia complex infection) before identification of the first $B$ multivorans isolate. The patient was exposed to multiple antibiotics, potentially leading to the emergence of infection with unusual respiratory pathogens. However, $B$ multivorans has not previously been reported in patients with bronchiectasis requiring frequent courses of antibiotics. This makes "antibiotic pressure" an unlikely sole cause of persistence of this organism in our patient with no evidence of structural airway damage on HRCT scanning. It is possible that $B$ multivorans may have been present before the patient's first visit to our centre, but was not identified as it is not routinely looked for in samples from the community. Our local laboratory has expertise in CF microbiology and is more likely to have followed up this unusual isolate.

The multiple immunodeficiencies found in this patient undoubtedly played a vital role in her susceptibility to recurrent lower respiratory tract infections. These are summarised in table 1 .

Clearance of pneumococci is dependent on serotype specific antibody to capsular polysaccharide, with a bias towards IgG2 antibody production in adults. The neutrophil receptor CD32 (Fc $\gamma$ RIIa) has two allelic forms that exhibit differential affinity for the Fc portion of IgG2. Receptors with arginine at position 131 (FcyRIIa-Arg 131) bind Fc poorly, whereas the histidine variant (Fc $\gamma$ RIIa-His 131) binds avidly. ${ }^{12}$ If antibody is present on the bacterial surface but Fc is bound only weakly to Fc $\gamma$ RIIa receptors, normal phagocytosis may not occur. The Arg 131/Argl31 homozygous allotype for CD32 is associated with a significantly increased incidence of bacteraemic pneumococcal pneumonia. ${ }^{13}$ This allotype, in addition to specific antibody deficiency to Pneumovax II, contributed to the overall risk of pneumococcal infection in our patient.

\section{Mannose binding lectin (MBL)}

MBL is a serum protein involved in innate immune defence. It is part of the collectin family of proteins, including surfactant proteins A and D, with a similar function and structure. ${ }^{14}$ It binds carbohydrates such as mannose on the surface of microorganisms, leading to activation of the complement pathway thereby facilitating phagocytosis. Direct opsonisation also occurs via collectin receptors on the phagocyte surface.

The human MBL genes (MBL1 and MBL2) have been localised to chromosome 10q11.1-21. ${ }^{15}{ }^{16} \mathrm{MBL1}$ is a pseudogene and MBL2 (the functional gene) consists of four exons,

Table 2 MBL2 polymorphisms

\begin{tabular}{|c|c|c|c|}
\hline Classification & Polymorphism & Nomenclature & MBL protein levels† \\
\hline $\begin{array}{l}\text { "Structural" (coding) } \\
\text { single nucleotide } \\
\text { polymorphisms (within exon 1) }\end{array}$ & $\begin{array}{l}\text { Codon } 52(\text { Arg } \rightarrow \text { Cys) } \\
\text { Codon } 54(\text { Gly } \rightarrow \text { Asp) } \\
\text { Codon } 57(G l y \rightarrow \text { Glu })\end{array}$ & $\begin{array}{l}\text { Allele C } \\
\text { Allele B } \\
\text { Allele D }\end{array}$ & $\begin{array}{l}\text { Low }(100 \mu \mathrm{g} / \mathrm{l}) \\
\text { Low }(100 \mu \mathrm{g} / \mathrm{l}) \\
\text { Low }(250 \mu \mathrm{g} / \mathrm{l})\end{array}$ \\
\hline $\begin{array}{l}\text { Promoter region single } \\
\text { nucleotide substitutions }\end{array}$ & $\begin{array}{l}-550 \mathrm{~g} \rightarrow \mathrm{c} \text { (alleles } \mathrm{H} / \mathrm{L} \text { ) } \\
-221 \mathrm{c} \rightarrow \mathrm{g} \text { (alleles } \mathrm{X} / \mathrm{Y} \text { ) } \\
+4 \mathrm{c} \rightarrow \mathrm{t} \text { (alleles } \mathrm{P} / \mathrm{Q} \text { ) }\end{array}$ & $\begin{array}{l}\text { HYA* } \\
\text { LYA }^{*} \\
\operatorname{LXA}^{*}\end{array}$ & $\begin{array}{l}\text { High }(>3500 \mu \mathrm{g} / \mathrm{l}) \\
\text { High }(>2000 \mu \mathrm{g} / \mathrm{l}) \\
\text { Intermediate } \\
(<1000 \mu \mathrm{g} / \mathrm{l})\end{array}$ \\
\hline $\begin{array}{l}\text { Compound heterozygotes } \\
\text { (promoter polymorphisms linked } \\
\text { to structural polymorphisms) }\end{array}$ & $\begin{array}{l}\text { HY }-52 \text { Cys } \\
\text { LY }-54 \text { Asp } \\
\text { LY }-57 G l u\end{array}$ & $\begin{array}{l}\text { HYAD } \\
\text { LYB } \\
\text { LYC }\end{array}$ & $\begin{array}{l}\text { Intermediate }(1000 \mu \mathrm{g} / \mathrm{l}) \\
\text { Low }(100 \mu \mathrm{g} / \mathrm{l}) \\
\text { Low }(200 \mu \mathrm{g} / \mathrm{l})\end{array}$ \\
\hline
\end{tabular}


exon 0 being non-coding. ${ }^{16}$ The resulting protein consists of three oligomers, each with three identical $32 \mathrm{kDa}$ polypeptide chains, and is produced in the liver. ${ }^{17}$

\section{$M B L 2$ polymorphisms}

These are summarised in table 2. Of the structural polymorphisms described below, A denotes a normal allele whereas $\mathrm{B}, \mathrm{C}$, and $\mathrm{D}$ are abnormal and may be referred to as $\mathrm{O}$ in some laboratories. Hence, heterozygotes are often referred to as $\mathrm{A} / \mathrm{O}$ genotype in the literature.

Our patient was a compound heterozygote for the structural polymorphism C/A (that is, 52 Cys) as well as a promoter polymorphism LY/HY ( $-500 \mathrm{~g} \rightarrow$ c substitution). Her MBL genotype is therefore HYAC and her MBL protein levels are predicted to be low at $<500 \mu \mathrm{g} / \mathrm{l}$ (see table 2 and Garred et $\left.a l^{18}\right)$.

Effect of MBL2 genotype on MBL protein levels

MBL is a functional polymer that is critically disrupted when even one of the polypeptide chains in the polymer carries an exon 1 polymorphism (table 2 ). Current detection methods include antibody detection using ELISA and functional assays of MBL binding. These methods select preferentially for higher order oligomerised MBL forms so they may not detect MBL antigen in MBL variant allele carriers. Garred and colleagues $^{18}$ analysed 1183 different serum samples using an ELISA method and a new anti-MBL monoclonal antibody. They ascertained that serum obtained from A/A individuals (that is, with normal MBL levels) contained predominantly high molecular weight $\mathrm{MBL}$, while serum samples from donors with a heterozygote genotype $(\mathrm{A} / \mathrm{O})$ contained both high and low molecular weight MBL. Furthermore, only high molecular weight MBL oligomers bound efficiently to mannan, enabling complement activation. Therefore, although the variant $M B L$ genotypes give rise to higher levels of MBL than was previously thought, this variant MBL is dysfunctional. Variant MBL is also cleared from plasma more quickly than the wild type, suggesting enhanced degradation of the abnormal protein. ${ }^{19}$ Measuring MBL levels is not therefore as informative as determining the genotype in deciding whether or not a patient has impaired MBL function.

MBL2 variant alleles causing reduced levels of MBL have been associated with an increased susceptibility of children and adults to infections. ${ }^{20-22}$ Patients with combined variable immunodeficiency (CVID) have an earlier onset of disease if low MBL protein producing allele variants are present than CVID patients with normal MBL2 alleles. ${ }^{6}$ This study highlights the importance of $M B L 2$ variants in increasing susceptibility to infection, especially in patients in whom immunity is already compromised. In CF, MBL deficiency is reported to be associated with significantly reduced lung function with variant allele carriers displaying particular susceptibility to infection with Burkholderia complex. ${ }^{23}$ Davies and colleagues ${ }^{24}$ have since discovered that MBL binds to Burkholderia complex leading to complement activation.

This unusual case illustrates chronic $B$ multivorans respiratory infection in a probable non-CF patient with no HRCT evidence of bronchiectasis. The patient was MBL deficient in addition to multiple other immunodeficiencies, which is the likely explanation for her susceptibility to unusual respiratory pathogens. Future treatment options for this patient may include immunoglobulin.

We suggest that a careful microbiological assessment is undertaken in patients with recurrent respiratory infection and that the presence of $B$ multivorans should trigger further immunological investigation including assessment of MBL status.

\section{Authors' affiliations}

J L Whitehouse, A R Exley, D Bilton, Lung Defence Clinic, Papworth Hospital, Cambridge, UK

A R Exley, Department of Immunology, Papworth Hospital, Cambridge, UK

J Foweraker, Health Protection Agency, Clinical Microbiology and Public Health Laboratory, Papworth Hospital, Cambridge, UK

Correspondence to: Dr J L Whitehouse, Lung Defence Clinic, Papworth Hospital, Papworth St Everard, Cambridgeshire CB3 8RE, UK; jo_wh@ excite.com

Received 28 September 2003

Accepted 6 March 2004

\section{REFERENCES}

1 Ledson MJ, Gallagher MJ, Walshaw MJ. Chronic Burkholderia cepacia bronchiectasis in a non-cystic fibrosis individual. Thorax 1998;53:430-2.

2 Kayhty H, Ahman H, Ronnberg PR, et al. Pneumococcal polysaccharidemeningococcal outer membrane protein complex conjugate vaccine is immunogenic in infants and children. J Infect Dis 1995;172:1273-8.

3 Musher DM, Groover JE, Watson DA, et al. Genetic regulation of the capacity to make immunoglobulin $G$ to pneumococcal capsular polysaccharides. $J$ Invest Med 1997;45:57-68.

4 Sorensen RU, Moore C. Antibody deficiency syndromes. Pediatr Clin North Am 2000;47:1225-52.

5 Sleeman K, Knox K, George R, et al. Invasive pneumococcal disease in England and Wales: vaccination implications. J Infect Dis 2001;183:239-46.

6 Mullighan CG, Marshall SE, Welsh KI. Mannose binding lectin polymorphisms are associated with early age of disease onset and autoimmunity in common variable immunodeficiency. Scand J Immunol 2000;51:111-22.

7 Burkholder W. Sour skin, a bacterial rot of onions. Phytopathology 1950:40:115-8.

8 Govan JR, Nelson JW. Microbiology of cystic fibrosis lung infections: themes and issues. J R Soc Med 1993;86(Suppl 20):11-8.

9 Winkelstein JA, Marino MC, Johnston RB Jr, et al. Chronic granulomatous disease. Report on a national registry of 368 patients. Medicine (Baltimore) 2000;79:155-69.

10 Holmes A, Nolan R, Taylor R, et al. An epidemic of Burkholderia cepacia transmitted between patients with and without cystic fibrosis. J Infect Dis 1999; 179: 1197-205.

11 Speert DP. Advances in Burkholderia cepacia complex. Paediatr Respir Rev 2002;3:230-5.

12 Warmerdam PA, van de Winkel JG, Vlug A, et al. A single amino acid in the second Ig-like domain of the human Fc gamma receptor II is critical for human lgG2 binding. J Immunol 1991;147:1338-43.

13 Yee AM, Phan HM, Zuniga R, et al. Association between FcgammaRlla-R131 allotype and bacteremic pneumococcal pneumonia. Clin Infect Dis 2000;30:25-8.

14 Turner MW. Mannose-binding lectin: the pluripotent molecule of the innate immune system. Immunol Today 1996;17:532-40.

15 Sastry K, Herman GA, Day L, et al. The human mannose-binding protein gene. Exon structure reveals its evolutionary relationship to a human pulmonary surfactant gene and localization to chromosome 10. J Exp Med 1989;170:1175-89.

16 Taylor ME, Brickell PM, Craig RK, et al. Structure and evolutionary origin of the gene encoding a human serum mannose-binding protein. Biochem $J$ 1989;262:763-71.

17 Ezekowitz RA, Day LE, Herman GA. A human mannose-binding protein is an acute-phase reactant that shares sequence homology with other vertebrate lectins. J Exp Med 1988;167:1034-46.

18 Garred P, Larsen F, Madsen HO, et al. Mannose-binding lectin deficiencyrevisited. Mol Immunol 2003;40:73-84

19 Naito H, lkeda A, Hasegawa K, et al. Characterization of human serum mannan-binding protein promoter. J Biochem (Tokyo) 1999;126:1004-12.

20 Garred P, Madsen HO, Hofmann B, et al. Increased frequency of homozygosity of abnormal mannan-binding-protein alleles in patients with suspected immunodeficiency. Lancet 1995;346:941-3.

21 Koch A, Melbye M, Sorensen $P$, et al. Acute respiratory tract infections and mannose-binding lectin insufficiency during early childhood. JAMA 2001;285:1316-21.

22 Summerfield JA, Ryder S, Sumiya M, et al. Mannose binding protein gene mutations associated with unusual and severe infections in adults. Lancet 1995;345:886-9.

23 Garred P, Pressler T, Madsen $\mathrm{HO}$, et al. Association of mannose-binding lectin gene heterogeneity with severity of lung disease and survival in cystic fibrosis. J Clin Invest 1999;104:431-7.

24 Davies J, Neth $\mathrm{O}$, Alton $\mathrm{E}$, et al. Differential binding of mannose-binding lectin to respiratory pathogens in cystic fibrosis. Lancet 2000;355:1885-6. 